\title{
Mapeamento geomorfológico em escala de semidetalhe da região de Jundiaí-Atibaia
}

\author{
Celso Dal Ré Carneiro ${ }^{(1)}$ e Juliano José de Souza ${ }^{(1)}$ \\ 1 Departamento de Geociências Aplicadas ao Ensino, \\ Instituto de Geociências UNICAMP. \\ Caixa Postal 6152, CEP 13083-970, Fax +55 (19) 3289 1562, \\ Campinas, SP, Brasil. E-mail: cedrec@,ige.unicamp.br
}

\begin{abstract}
RESUMO
A região de Jundiaí-Atibaia, localizada a norte-noroeste da capital paulista, vem sendo submetida a forte processo de urbanização, que se estende sobre um substrato rochoso constituído de rochas foliadas e intemperizadas. A falta de dados mais pormenorizados sobre o relevo, unidades litológicas e estruturas tem gerado problemas de risco geológico, levando-se em conta certos padrões de ocupação, específicos e mais apropriados para as colinas paulistanas e vertentes suaves dos espigões urbanos de São Paulo. Esse contexto gera a necessidade de se dispor de uma cartografia adequada (mapas geológicos, geomorfológicos etc.) para orientar o processo de ocupação. O mapa geomorfológico da área foi produzido com recursos de Sistemas de Informações Georreferenciadas (SIG), fotointerpretação e levantamentos de campo. Foram gerados Modelos Digitais de Terreno (MDTs), mapas de declividades e hipsométricos a partir de uma base planialtimétrica em meio digital, utilizando-se os software Arc/Info e Arc/View. Com base na textura de MDT, em tons de cinza, foram reconhecidos os padrões de forma de relevo e delimitados os contatos entre eles, levando-se em conta as quebras naturais do relevo (rupturas positivas, rupturas negativas e outras feições). A delimitação dos contatos foi, posteriormente, refinada e aferida por meio de fotos aéreas (1:25.000) e do mapa topográfico. Feições de erosão laminar, pequenas soleiras locais, reentalhamento de canais de primeira ordem e campos de matacões, observados em fotos aéreas, foram lançados, junto com os contatos, na cópia do mapa-base em papel, para digitalização. Organizou-se um banco de dados com informações georreferenciadas contendo descrições de campo sobre processos de ravinamento, escorregamentos e erosões, além de dados sobre formas do relevo e coberturas detríticas, para analisá-los em ambiente SIG e lançá-los no mapa final. O mapa geomorfológico digital resultante do projeto encontra-se na escala 1:25.000, devendo apoiar novos estudos de uso e ocupação. A pesquisa ressalta a necessidade de se dispor de estudos prévios de morfologia e geologia, antes da abertura de estradas e loteamentos, para apoiar a prevenção e/ou minimização de acidentes geológicogeotécnicos.
\end{abstract}

Palavras chave: Sistemas de Informação Geográfica, mapeamento geomorfológico, banco de dados, Atibaia.

\begin{abstract}
The region of Jundiaí-Atibaia, located north-northwest of the capital of the São Paulo State, is being submitted to a fast urbanization process, on a rocky substratum consisting of foliated weathered rocks. The lack of more detailed data on relief, lithological units and structures has generated problems of geologic risk. The standards of occupation were formerly developed for the soft urban hills of the São Paulo city. This context requires geological and geomorphological maps, as cartographic tools suitable to guide the occupation process. The project was directed towards production of a morphologic map of the area, using Geographic Information Systems (GIS), photointerpretation and field surveys. From a digital planialtimetric base, it has been produced a Digital Terrain Model (DTM), hypsometric maps and declivity maps using software Arc/Info and Arc/View. The grayscale texture of the DTM allows the relief patterns to be recognized as well as the contacts between them. The contacts were later refined and surveyed by means of aerial photographs (scale 1:25.000) and topographical maps (1:25.000), taking into account the natural relief ruptures (positive ruptures, negative ruptures and other features). Aerial photographs were also interpreted for identification of laminar erosion features, small rock outcrops along drainage, re-sculpture of first-order channels and boulder fields. All these information were vetorized, together with the contacts. A database containing such georeferred information was organized after fieldwork. Gully processes, rock slips and erosions, as well as data on relief forms and detritic covers were described, in order to analyze them in a GIS environment and to integrate the information on maps. As a result of the project a digital geomorphologic map, in scale 1:25.000, may support new use and occupation studies. The research also points out the need for making use of geomorphology and geology surveys before road construction and land division, to prevent geologic-geothecnical hazards.
\end{abstract}

Key Words: System of Geographical Information, geomophological cartography, data base, Atibaia. 


\section{Introdução}

Situada a norte da capital paulista, a região entre os municípios de Jundiaí e Atibaia vem sendo submetida a forte pressão pela ocupação urbana que incide, em particular, sobre a transição entre um domínio de morros e morrotes, a norte, para zonas mais acidentadas a sul e mais próximas a São Paulo. Esta região está localizada na Província do Planalto Atlântico, contendo duas zonas geomorfológicas: Planalto de Jundiaí e Serrania de São Roque. A região foi objeto de mapeamento geológico (Carneiro 2001) no projeto Evolução crustal da região de JundiaíAtibaia e implicações conceituais para ensino de campo em Geologia e planejamento da ocupação. Os trabalhos buscam atender à necessidade de se considerar no planejamento municipal os tipos de modelados (Guerra \& Cunha, 1998) e os fatores condicionantes do relevo (Fernandes et al. 2000). No projeto geotécnico dessas áreas devem ser aplicados conhecimentos de Geologia, Geologia Estrutural e Geomorfologia (Carneiro 1999), por meio da cartografia sistemática do modelado do relevo e das variações de orientação de estruturas.

O acompanhamento e controle da expansão urbana dependem de bases geológicogeomorfológicas adequadas; assim, o objetivo central da pesquisa foi interpretar as formas de relevo e produzir um mapa geomorfológico, tentativamente na escala 1:25.000. Problemas identificados na área entre Campo Limpo e Francisco Morato, como por exemplo a fixação da população em loteamentos ou invasões em encostas íngremes e ocupação de áreas de baixadas (Carneiro 2000), são freqüentes em outras regiões da periferia paulistana. No primeiro caso, há risco de erosão acelerada e escorregamentos, e, no segundo, risco de assoreamento e inundações localizadas.

\section{Localização}

A área estudada situa-se na porção centrosudeste do Estado de São Paulo. Aquadrícula limitada pelas coordenadas 23'10'00" - 23 ' '7'30" S e 4633'45" - 4652'30" WG foi objeto de mapeamento ( Figura. 1).

$\mathrm{O}$ acesso à área se faz pelas rodovias Anhangüera (SP-340), dos Bandeirantes (SP-348), D. Pedro I (SP-65) e Cajamar-Campo Limpo-Jarinu (SP354), além de densa malha de vias locais e interurbanas, que facilitam o acesso aos pontos de estudo.

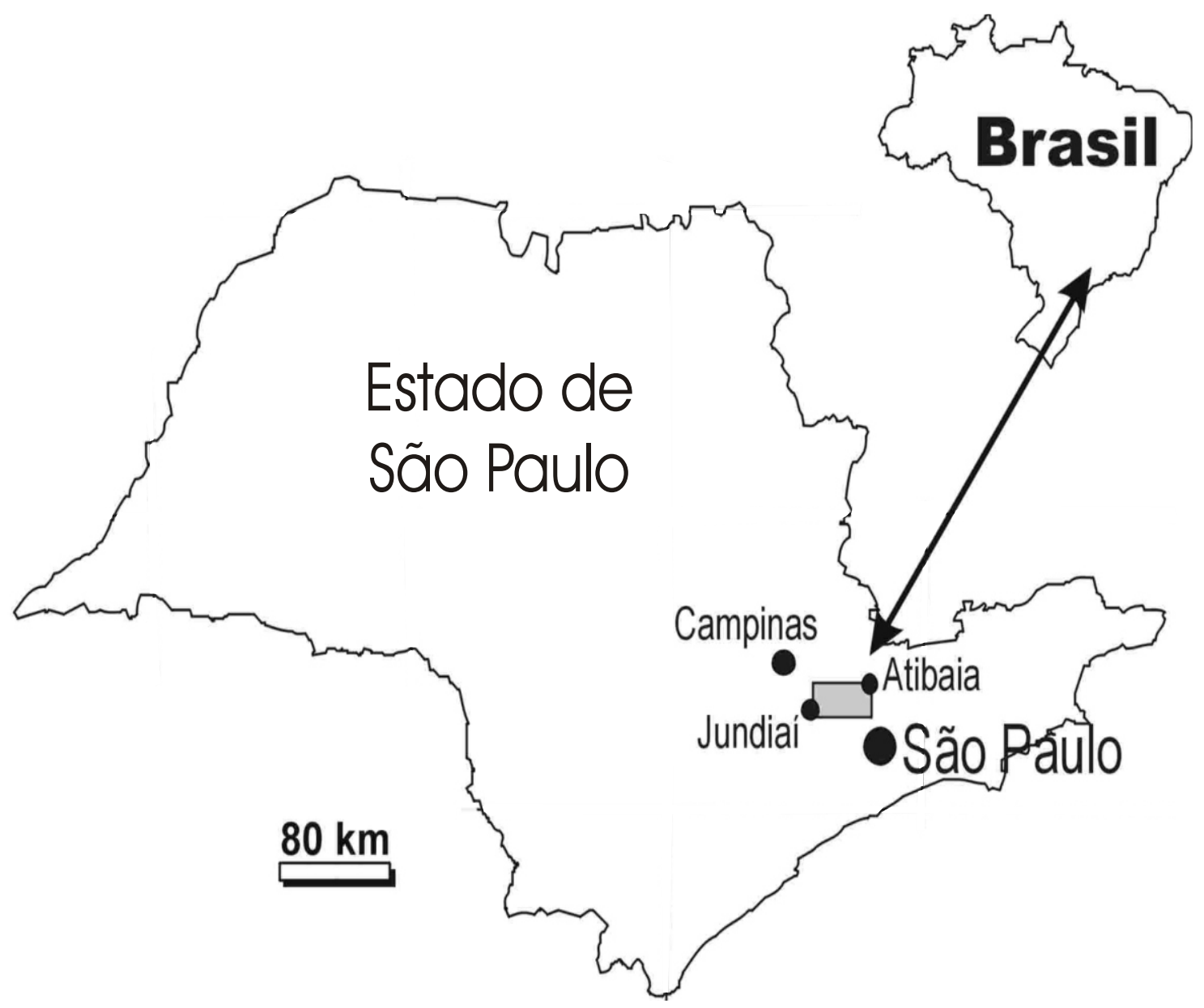

Figura 1: Mapa de localização da área estudada, entre Jundiaí e Atibaia (SP) 
A área engloba partes dos municípios de Jundiaí, Atibaia, Campo Limpo Paulista, Várzea
Paulista, Jarinu, Franco da Rocha, Mairiporã e Francisco Morato (Figura. 2).

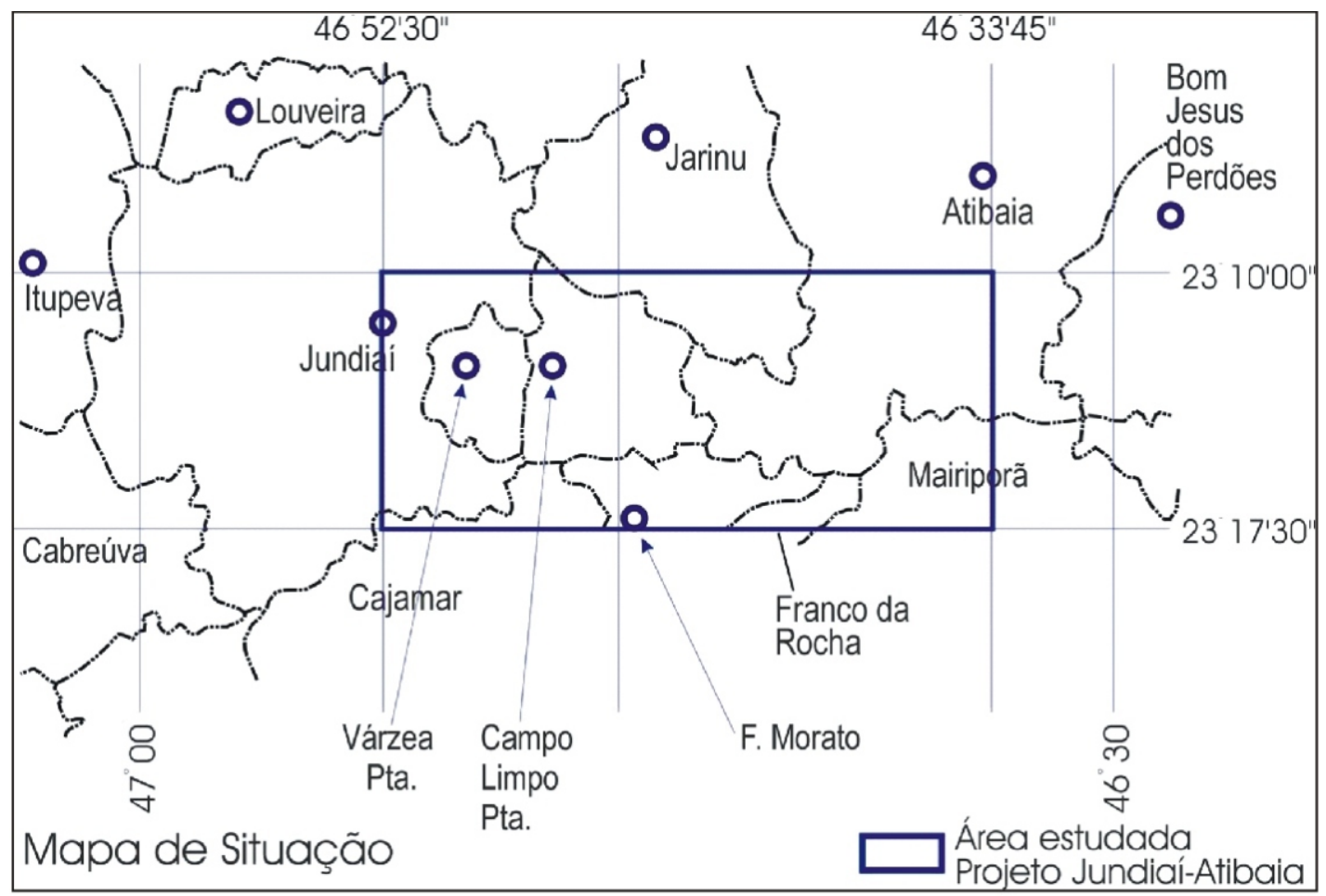

Figura 2: Limites municipais e distribuição das cidades abrangidas pelo estudo.

\section{Metodologia}

Na elaboração do trabalho foram integradas as informações anteriores produzidas pela equipe do projeto ou obtidas na literatura, como os mapas geomorfológicos de escala regional do Estado de São Paulo (Carneiro et al. 1981, Ross e Moroz 1997). Foi realizada interpretação de fotos aéreas, imagens de satélite e mapas topográficos. As etapas de campo destinaram-se à coleta de dados e checagem de informações fotointerpretadas. A utilização de SIG voltou-se para análise, integração e produção de mapas, baseados nos seguintes documentos e materiais:

- Folhas plani-altimétricas do Projeto MacroMetrópole, escala 1:10 000;

- Carta plani-altimétrica do Município de

Várzea Paulista, escala 1:10 000, sem data;

- Cartas plani-altimétricas (parciais) do Município de Jundiaí, escala 1:10 000, 1994;

- Arquivos vetoriais de quinze folhas planialtimétricas elaboradas a partir do Projeto MacroMetrópole, escala original 1:10 000 (Projeto Jundiati);

- Banco de dados das descrições de campo (Projeto Jundiati);

- Banco de fotografias de campo (Projeto Jundiati);

- Cópias de fotografias aéreas da Secretaria da Agricultura do Estado de São Paulo, Instituto
Agronômico, 1962, escala aproximada 1:25 000, foto-índice O-M, região 7;

- Bases geomorfológicas, escala original 1:250 000, contendo elementos de interpretação segundo o conceito de sistemas de relevo;

- Mapa Geológico da Região de JundiaíAtibaia, escala 1:25.000 e 1:50.000 (Projeto Jundiati - Carneiro 2001);

- Imagem LANDSAT TM 5, 219/76 W 23-091992, composta por seis bandas $(1,2,3,4,5$ e 7$)$.

Interpretação de fotos aéreas, imagens de satélite e mapas topográficos

A interpretação de fotos aéreas possibilitou reconhecer as unidades de relevos e mapear algumas feições em detalhe, como: reentalhamento de canais, evidências de erosão acelerada, presença de matacões, escorregamentos, pequenas soleiras locais e reconhecimento de coberturas coluvionares. Os dados fotointerpretados foram traçados em overlay de filme de transparência sobreposto às fotos aéreas, utilizando-se canetas hidrográficas especiais para transparências, a partir das quais foi efetuada a digitalização.

A imagem LANDSAT 5 foi tratada por meio do software ER MAPPER, para visualizar e delimitar as formas de relevo da área, aplicando-se a técnica de primeira componente principal (PC1), com objetivo de ressaltar texturas. Outra tentativa foi trabalhar somente com a banda 4 em tons de cinza, já que esta se 
mostrou a melhor para visualizar a textura da imagem. Os resultados foram parcialmente aproveitados, pelo fato de a imagem mostrar diferenças texturais é perder-se definição, na escala de semidetalhe. $\mathrm{O}$ uso das imagens possibilitou observar a distribuição das manchas de ocupação na área.

A partir dos mapas topográficos obteve-se a amplitude relativa do relevo e o comprimento de rampa, além da visualização e descrição das formas de relevo da área, níveis de base locais, situação dos pontos mais altos, presença de formas de dissecação do relevo e domínios sucessivamente maiores na hierarquia da rede de drenagem.

\section{Utilização de SIG}

As bases cartográficas foram inseridas em Sistemas de Informações Geográficas (SIG), com utilização dos seguintes software: AutoCad, Arc/Info e ArcView. O banco de dados de campo do projeto foi atualizado com novos dados específicos sobre o relevo. A partir da base digital geraram-se mapas clinométricos, mapas hipsométricos, mapas de cálculo de densidade de drenagem, Modelos Digitais de Terrenos MDTs e perfis topográficos. Os MDTs, em tons de cinza, possibilitaram reconhecer e delimitar diferentes padrões de relevo, com base na textura (rugosidade) do modelo. As unidades delimitadas foram refinadas com auxilio das fotos aéreas e dos mapas topográficos em escala 1:50.000 e 1:25.000. Os limites entre tipos de relevo foram delimitados utilizando-se, principalmente, as rupturas mais expressivas do relevo (positivas e negativas) e, de maneira secundária, a rede hidrográfica e divisores d'água (Pires Neto, 1991).

\section{Etapa de campo}

As informações inseridas no banco de dados previamente organizado e aprimorado durante os trabalhos de mapeamento, consistem de descrições de processos de ravinamento, reentalhamentos de canais de drenagem, escorregamentos, deslizamentos, assoreamentos, boçorocas e campos de matacões, além de dados sobre formas do relevo e coberturas detríticas. Os trabalhos de campo tiveram o objetivo de coletar dados adicionais e examinar as feições fotointerpretadas, a partir do esboço do mapa geomorfológico e da base cartográfica em escala $1: 25.000$.

\section{Integração de dados e produção do mapa geomorfológico}

A sistematização e análise dos dados obtidos deram origem ao mapa geomorfológico em escala $1: 25.000$. Os dados fotointerpretados foram transferidos para um mapa-base, a partir do qual realizou-se o processo de digitalização. Em ambiente SIG (software Arcview 3.1), fez-se o processo de integração, análise, interpretação e cruzamento dos dados; e edição do mapa geomorfológico final.

\section{Resultados e Discussões}

\section{Geologia regional}

A área situada entre as cidades de Jundiaí e Atibaia está contida no Sistema de Dobramentos Sudeste (Hasui, Almeida, Brito-Neves, 1978) da Província Mantiqueira (Almeida et al, 1977). O sistema foi consolidado no intervalo entre o final do Proterozóico e o Cambro-Ordoviciano. Divide-se em faixas ou blocos tectônicos, afetados por eventos termo-tectônicos e abundante formação de granitos brasilianos. Em diversos pontos da região $\mathrm{SE}$ do Estado de São Paulo ocorrem rochas atribuídas ao Arqueano e mais novas, constituindo uma estrutura regional complexa que tem sido sujeita a diversas interpretações. O mais recente mapa de síntese disponível da geologia de São Paulo (Bistrichi et al., 1981) acompanha a revisão do arcabouço tectônico (Almeida et al., 1981) e constitui referência para a litoestratigrafia e estrutura regionais. $\mathrm{Na}$ região afloram stocksgraníticos sin- a tardicinemáticos. Os corpos graníticos pertencem ao Neoproterozóico, durante a consolidação da Plataforma Sul-Americana (entre 600 e $450 \mathrm{Ma}$ ). No final do Neoproterozóico, extensas falhas transcorrentes foram geradas pelo arrefecimento do calor e pela mudança no regime de esforços.

As unidades litológicas presentes (Carneiro, 2001) são o Complexo Itapira e o Grupo São Roque. As rochas afloram, freqüentemente, e se encontram em estágio de adiantada decomposição. O Complexo Itapira (Paleo-Mesoproterozóico) compreende associações dobradas onde predominam xistos e metarenitos, portadores de inúmeras intercalações de quartzitos, anfibolitos e alguns termos gnáissicos. $\mathrm{O}$ Grupo São Roque (Neoproterozóico) constitui-se de rochas metapsamíticas, metapelíticas, químicas e químico-detríticas.

De sul para norte, os limites da área de distribuição das rochas do Grupo São Roque coincidem aproximadamente com o divisor de águas das bacias do rio Juqueri com os rios Jundiaí e seu principal formador, o rio Jundiaizinho. Os rios Jundiaí e Jundiaizinho correm na maior parte desse trecho sobre metarenitos e xistos correlacionados ao Complexo Itapira. As cabeceiras da bacia do rio Jundiaizinho, bem como o divisor de águas desta rede de drenagem com a bacia do Rio Atibaia, mais a norte, situam-se inteiramente sobre rochas gnáissicas e migmatíticas correlacionadas à Formação Jundiuvira do Complexo Itapira.

A região apresenta coberturas mais jovens, como sedimentos permo-carboníferos do subgrupo Itararé, restritos a manchas semicirculares no extremo noroeste da área, delimitados por falhas normais (Neves, 1999). Trata-se de sedimentos paleozóicos de 
origem glacial correlacionáveis ao Grupo Itararé, identificados pela presença de alternâncias rítmicas de níveis argilosos e siltosos. São argilitos, siltitos, diamictitos, folhelhos e ritmitos, que se encontram alterados, que têm sido explotados por indústrias cerâmicas locais e pelas indústrias produtoras de agregados de argilas expandidas. As coberturas cenozóicas estão representadas por sedimentos correlatos à Formação São Paulo, depósitos coluvionares e aluvionares.

\section{Geomorfologia regional}

A região em estudo é constituída por duas zonas geomorfológicas: Serrania de São Roque e Planalto de Jundiaí, definidas respectivamente por Almeida (1964) e Ponçano et al. (1981). Ambas pertencem à província Planalto Atlântico. A área faz parte de extensos domínios dos "mares de morros florestados" do Brasil Sudeste (Ab'Saber, 1992), que incluem muitos trechos de pequenas serras e picos quartzíticos como a própria Serra do Japi. A evolução geomorfológica, durante a transição do Cretáceo para o Terciário, envolveu extensivo soerguimento do sudeste brasileiro, tendo deformado a superfície de aplainamento Japi e envolvido a formação de superfícies de aplainamento mais jovens, pós-Japi.

A serrania de São Roque situa-se a sul da região, tendo sido definida por Almeida (1964) como:

(...) "o mais típico entre os planaltos cristalinos paulistas, não só pela diversidade de suas estruturas e formas de seu acidentado relevo como pela clara participação que em sua origem tiveram as superfícies de aplainamento Itaguá e Japi." (Almeida 1964).

A serrania é composta em sua maioria por metamorfitos pertencentes ao Grupo São Roque, penetrados por intrusões de rochas graníticas. Suas maiores altitudes são alcançadas na Serra do Japi, com cerca de 1.200-1.250 metros, região que se localiza na vizinhança da área coberta pelo projeto. Já dentro da área em estudo, ela se prolonga ao longo das Serras dos Cristais, onde são suportadas por quartzitos e metarenitos bandados. As maiores elevações locais, como as serras da Mursa (ou do Mursa) e de Botujuru, formam acidentes geográficos notáveis, que se estendem segundo a direção leste-oeste. Fôra classificada por Ponçano et al. (1981) como Morros com Serras Restritas (245), tendo sido mapeada na extremidade leste como Serras Alongadas (251). A partir dessas serras, em direção a norte, a Serrania de São Roque dá lugar a relevos de morrotes, que fazem parte do Planalto de Jundiaí.

Predominam na região do Planalto de Jundiaí relevos de colinas e morros baixos com topos convexos (que em grande parte podem ser descritos como morrotes). Os morros e morrotes associam-se ao desenvolvimento das bacias de drenagem dos rios Jundiaí e Atibaia, sendo classificados no sistema de relevo de Mar de Morros (243) (Ponçano et al., 1981). O substrato litológico é formado por xistos, gnaisses, migmatitos e granulitos penetrados por granitos. Os topos das elevações no Planalto de Jundiaí apresentam-se uniformemente nivelados em torno de 820-870 metros, com os fundos de vales situados a cerca de 700-750 metros, na área estudada. Os depósitos sedimentares ao longo do rio Jundiaí devem-se à influência exercida pelo Maciço de Itu, que funciona como uma soleira local (Almeida, 1964).

Em uma síntese sobre as superfícies de erosão no território brasileiro, Ab'Saber (2000) discute o papel fundamental das superfícies de cimeira como resultado do modelamento erosivo das regiões elevadas do supercontinente Gondwana, fornecendo sedimentos para as bacias intracratônicas adjacentes. Almeida (1964) descreve o papel desempenhado pela superfície de aplainamento do Japi no controle das feições de relevo que se desenvolveram às bordas e na margem da Bacia do Paraná. Essa superfície representa o final de um longo processo erosivo e foi posteriormente deformada, durante o desenvolvimento do Sistema de Riftes da Serra do Mar (Almeid,a 1976) ou do Rifte Continental do Sudeste do Brasil (Riccomini, 1989). As deformações exerceram papel importante no desenvolvimento da Serra do Mar (Almeida \& Carneiro, 1998).

Apesar de reconhecer divergências entre os diversos trabalhos que referem, Ponçano \& Almeida (1993) assinalam existir uma concordância geral de que o término da "sedimentação cretácica completa a configuração de vasta superfície mais ou menos aplainada, cuja elaboração provavelmente se estendeu até o Terciário Inferior, sob condições predominantes de semi-aridez".

Contudo, destacam esses autores que nada se pode concluir sobre a origem dos planaltos dispostos "ao longo dos principais cursos d'água, e interpretados como pediplanos ou peneplanos dissecados", uma vez que (Ponçano \& Almeida (1993, p. 85) lembram que:

\footnotetext{
..."dada a situação destes planaltos, entre a superfície mais antiga e os terraços fluviais quaternários, é razoável considerar que representem eventos erosivos associados à primeira grande fase de aridez, relacionada a estágio glacial, cujos reflexos teriam afetado essas latitudes ao final do Terciário e inicio do Quaternário. Neste caso, similarmente à superfície cimeira, é provável que as superfícies erosivas então elaborada não correspondiam a uma única fase simples e bem definida".
}

Entre as superfícies pós-Japi, Ab'Saber (1992) destaca uma superfície de aplainamento "de caráter intermontano", que ficara contida entre a face norte da Serra do Japi e a "face sul da serra do Jardim região de Valinhos-Vinhedo". Tem sido aplicada a 
denominação "Superfície de São Roque Jundiaí" aos restos sub-nivelados desta superfície, cuja posição é intermediária no relevo regional. A fase principal de repronunciamento do Japi processou-se entre o período de aplainamento parcial São Roque - Jundiaí (870 - 930 metros) e a formação do nível das colinas que envolvem a bacia detrítica de Jundiaí (700 - 760 metros).

Neves (1999) destaca que, devido à distribuição de esforços nessa parte do continente, durante a separação e deriva da Placa Sul-Americana, houve no embasamento da borda ESE da Bacia do Paraná um abatimento do bloco central, formando as escarpas das serras do Japi e do Jardim. Provavelmente, a partir do Terciário Médio, os abatimentos de blocos desencadearam a instalação de sistemas de leques aluviais correspondentes aos depósitos terciários. Com a continuidade dos movimentos e o progressivo soerguimento da área, os falhamentos se acentuaram, provocando novos basculamentos de blocos e abatimento de algumas seqüências no embasamento cristalino. Houve remoção posterior de grande parte dos depósitos, mas alguns restos ficaram preservados e foram recobertos por coberturas coluvionares, formadas após o intemperismo e erosão destes e dos outros litotipos presentes. A movimentação continuou e os depósitos coluvionares, juntamente com as linhas de seixos, foram afetados por falhamentos, ficando sujeitos a processos erosivos.
As coberturas coluvionares, muito expressivas na região a norte da Serra do Japi, estendem-se para leste, até a região ora focalizada, entre Campo Limpo Paulista e Jundiaí. Os registros dessa evolução acham-se bem documentados em afloramentos de sedimentos terciários e quaternários; são coberturas cuja coluna freqüentemente se inicia por cascalheiras basais, no contato entre o embasamento e os sedimentos cenozóicos. Neves (1999) reconhece numerosas falhas que afetam as coberturas situadas a norte da Serra do Japi, denunciando atividade neotectônica regional.

\section{Compartimentação do relevo}

Os parâmetros adotados para caracterizar os tipos de relevo (Tabela 1) foram baseados em Ponçano et al. (1981). Primeiramente, procurou-se classificar o relevo com base nas formas dominantes, tendo como base a proposta de Sistemas de Relevo (Ponçano et al., 1979). O ponto de partida para o mapeamento foi um esboço da Folha São Paulo, na escala 1:250.000, do Mapa Geomorfológico do Estado de São Paulo desenvolvido pela equipe do IPT e posteriormente publicado por Ponçano et al. (1981), no qual se reconhecem quatro sistemas de relevo, na região de Jundiaí-Atibaia: Planícies Aluviais (111), Mar de Morros (243), Morros com Serras Restritas (245) e Serras Alongadas (251). Consultou-se também o Mapa Geomorfológico do Estado de São Paulo publicado por Ross et al. (1997), em escala 1:500.000.

Tabela 1: Classificação adotada para os tipos de relevo, modificada de Ponçano et al. (1981)

\begin{tabular}{|c|c|c|c|}
\hline locais & Amplitudes & $\begin{array}{l}\text { Declividades } \\
\text { predominantes }\end{array}$ & Tipos de relevo \\
\hline & $<100 \mathrm{~m}$ & $\begin{array}{l}<15 \% \\
5 \text { a } 15 \% \\
>15 \%\end{array}$ & $\begin{array}{l}\text { Rampas } \\
\text { Colinas } \\
\text { Morrotes }\end{array}$ \\
\hline & 100 a $300 \mathrm{~m}$ & $\begin{array}{l}5 \text { a } 15 \% \\
>15 \%\end{array}$ & $\begin{array}{l}\text { Morros com encostas suaves } \\
\text { Morros }\end{array}$ \\
\hline & $>300 \mathrm{~m}$ & $>15 \%$ & Montanhas \\
\hline
\end{tabular}

Graças à escala de semidetalhe adotada para este mapeamento, 1:25.000, foi possível discriminar e cartografar outras unidades, caracterizadas na Tabela2. As seguintes siglas foram adotadas na Figura 3: Pa - Planícies Aluviais, Col - Colinas, Cmc - Colinas e Morrotes de Cimeira, CMt - Colinas e Morrotes, MMt - Morros e Morrotes, Mr - Morros, Mta - Morros com Topos Agudos.

O relevo de Planícies Aluviais constitui-se de formas planas, predominantemente deposicionais, sendo mais expressivas ao longo do rio Jundiaí e no trecho do Ribeirão do Onofre (a sul de Atibaia) onde se encontram em contato com a unidade de relevo Colinas (Figura. 3). São sedimentos inconsolidados e material argilo-siltoso avermelhado a esbranquiçado, localmente arenoso. Alguns depósitos são explotados por olarias.

O relevo de Colinas está freqüentemente associado às coberturas detríticas, coluviões e sedimentos correlatos ao Subgrupo Itararé (PCi); além das rochas do embasamento cristalino (gnaisses, xistos etc.). Constituem formas de relevo mais suaves que favoreceram o processo de urbanização de algumas cidades, como Jundiaí, Várzea Paulista, Campo Limpo Paulista e Atibaia.

O relevo Colinas e Morrotes de Cimeira localiza-se na região de Terra Preta, na parte Sudeste da área, onde ocorrem topos subnivelados entre 9801040 metros. Sua transição, a norte, com a unidade de relevo Morros e Morrotes (MMt) e Morros (Mr) 


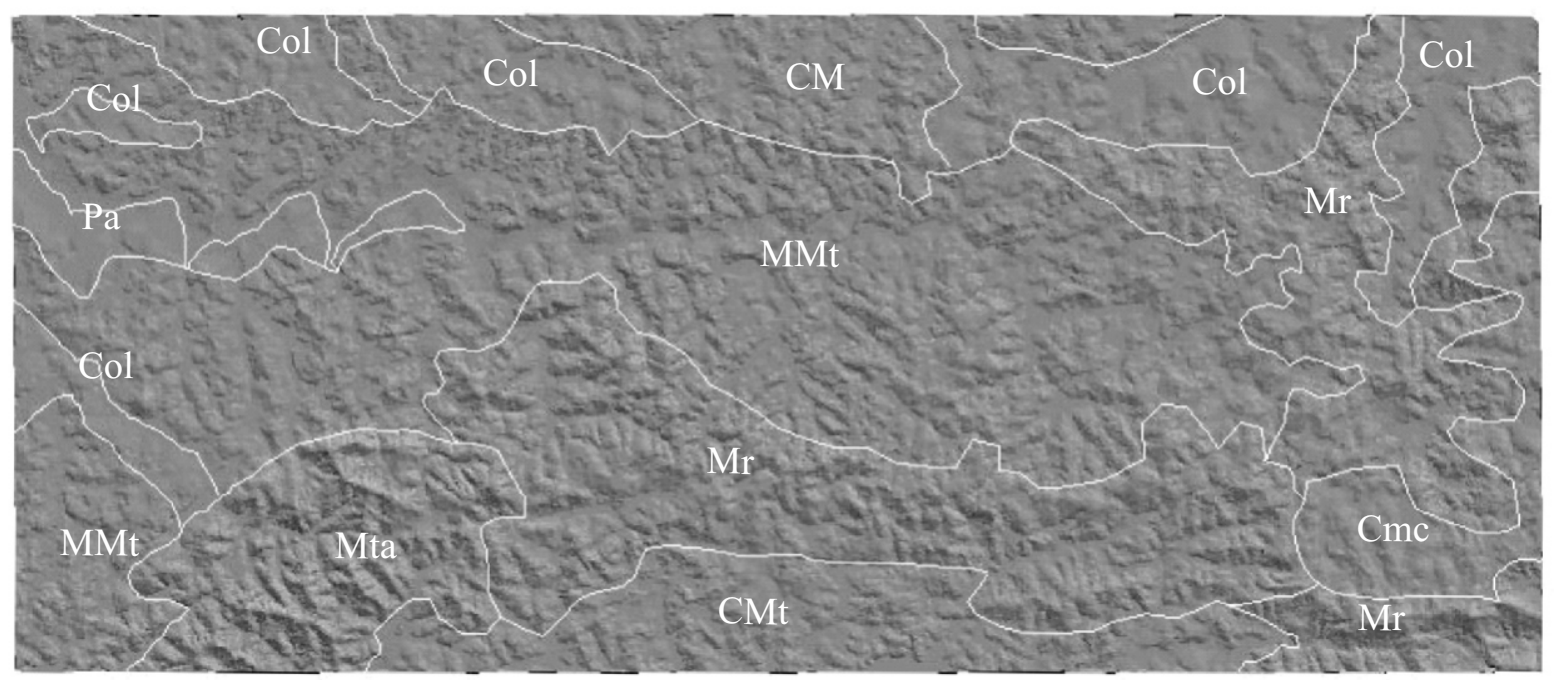

Figura 3: Esboço dos tipos de relevos sobreposto ao MDT, em tons de cinza. Siglas: Pa - Planícies Aluviais, Col Colinas, CMc - Colinas e Morrotes de Cimeira, CMt - Colinas e Morrotes, MMt - Morros e Morrotes, $\mathrm{Mr}$ - Morros, Mta - Morros com Topos Agudos. Escala aproximada 1:150.000

ocorre por contato em ruptura positiva. Asul, o contato ocorre por ruptura negativa com a unidade Morros. Este relevo é sustentado por xistos finos e granitos. A sul o contato ocorre por ruptura negativa com a unidade Morros.

O relevo Colinas e Morrotes encontra-se na região sul da área, entre Terra Preta e Francisco Morato; é caracterizado por topos subnivelados entre 750-890 metros, consistindo de formas estreitas, convexas e alongadas segundo orientações NE-SW e NW-SE. A transição, a norte e oeste, entre esta unidade de relevo e a unidade Morros (Mr), ocorre por contato em ruptura positiva.

O relevo de $\underline{\text { Morros }}$ é sustentado por xistos finos e granitos; estende-se ao longo da Serra de Botujuru, o prolongamento oeste da Serra dos Cristais, com direção mais ou menos E-W. A unidade de relevo atua como um divisor entre as bacias do rio Jundiaí (norte) e Juqueri (sul), sendo drenada por canais de alto curso de ambas as bacias citadas. Caracteriza-se como um relevo com alta energia potencial, predominando altas declividades, que favorecem processos intensos de erosão (ravinamento, erosão laminar etc.). Na região NE da área, nas proximidades da cidade de Atibaia, este tipo de relevo constitui um divisor entre a bacia do rio Jundiaí e Atibaia, e também apresenta alta energia potencial, evidenciada pelo intenso processo erosivo. Nos domínios de gnaisses e granitos, matacões freqüentemente afloram nas encostas.

A transição, a norte de Campo Limpo Paulista, das unidades de relevos Colinas e Colinas e Morrotes (norte) para Morros e Morrotes e Colinas e Morrotes (sul), ocorre por meio de ruptura positiva. O relevo a norte é drenado pelos afluentes do rio JundiaíMirim, cujas cotas de vales oscilam entre 750-800 metros e topos entre 800-900 metros. A sul o relevo é drenado pela bacia do Jundiaí, cujas cotas médias de vales são 706-750 metros e de topos 750-800 metros; esta encosta de transição é fortemente entalhada pelos afluentes da margem norte do Jundiaí.

O relevo de Morros com Topos Agudos, presente na região da Serra dos Cristais, constitui a zona mais acidentada da parte oeste da área (Figura. 4). O fato de conservar ainda grande parte de sua cobertura vegetal minimiza em parte os processos erosivos atuantes. Esta região serrana é sustentada principalmente pelas unidades metareníticas e quartzíticas do Grupo São Roque, que sustentam a unidade de relevos Morros com Topos Agudos e Morros, adiante descritos. A Serra dos Cristais atua como divisor entre as bacias do rio Juqueri (a sul) e a bacia do rio Jundiaí (a norte), e os canais que drenam o relevo são de alto curso. Alguns vales apresentam-se encaixados em linhas de falha, com direções NE-SW a E-W. A transição a norte para o relevo de Colinas e Morrotes é brusca, ocorrendo por ruptura positiva.

\section{Controle litoestrutural}

Correlações acerca do relevo local podem ser extraídas das informações geológicas, a partir dos mapas disponíveis. Parte desses levantamentos permanece inédita, sendo acessível somente em relatórios (Carneiro, 2001; CPRM, 1991) e dissertações acadêmicas (Neves, 1999). Algumas informações já obtidas são de grande interesse para caracterizar a evolução morfológica da paisagem da área.

A região apresenta lineamentos orientados preferencialmente nas direções NE-SW, NW-SE, E-W e N-S, que controlam a drenagem e consequentemente as orientações das vertentes. Os lineamentos NE-SW e E-W estão freqüentemente associados as falhas e zonas de cisalhamento que afetaram o embasamento. Neves (1999) destaca a existência de duas famílias de fraturas com direções predominante NW-SE e NE-SW 

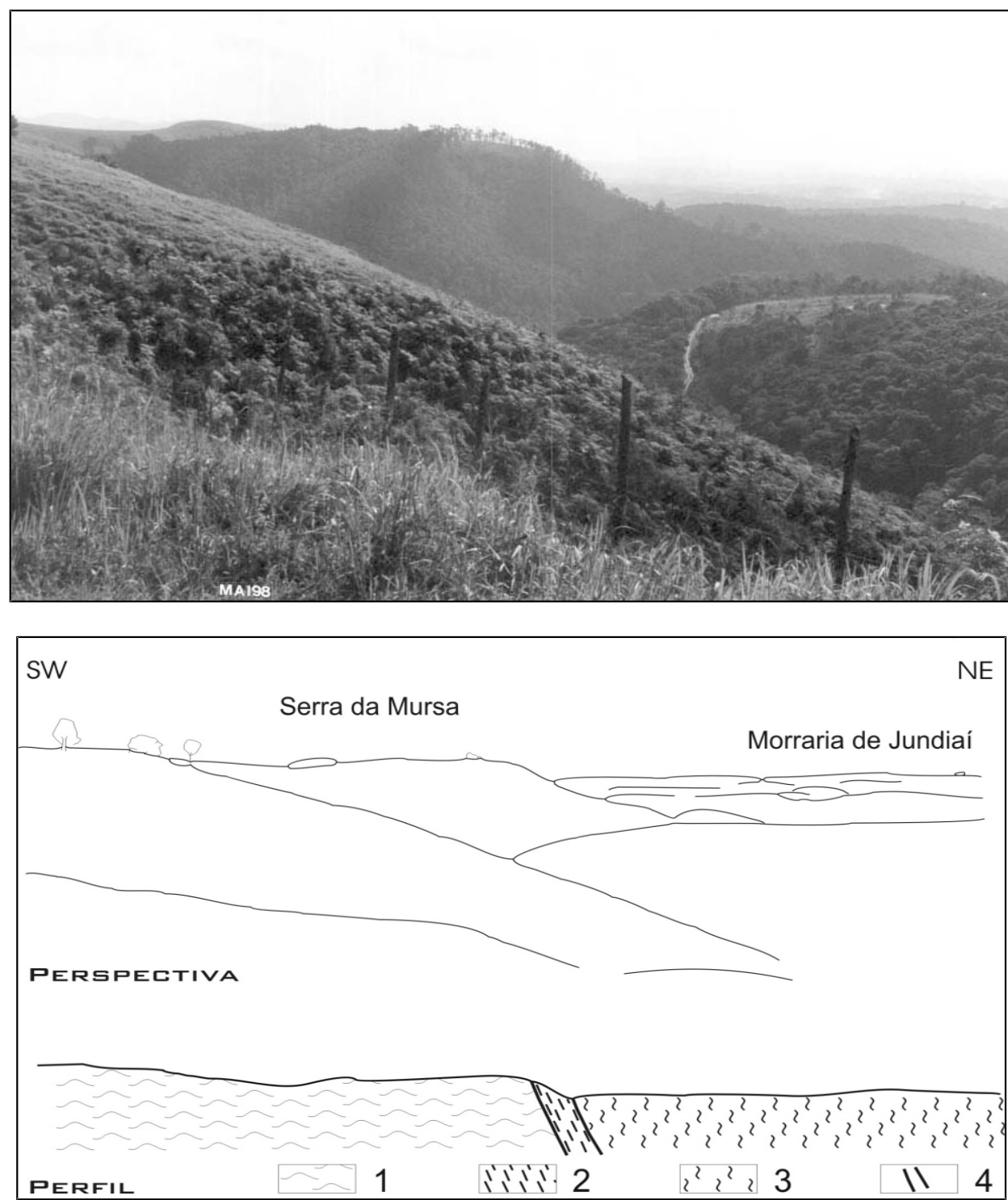

Figura 4: Fotografia, esquema em perspectiva e perfil geológico da área limítrofe entre a unidade Morros com Topos Agudos, na Serra dos Cristais e o relevo da Morraria de Jundiaí, ao fundo. Convenções: 1 - Grupo São Roque, 2 - Milonitos e ultramilonitos, 3 - Complexo Itapira, 4 - Contatos litológicos

com alto ângulo e a existência de falhas normais e inversas, além de transcorrentes, com direções NESW, NW-SE, E-W e N-S, que afetam o embasamento e controlam a formação e deformação dos depósitos sedimentares

No relevo Morros com Topos Agudos, Serra dos Cristais, com menor intensidade ao longo de toda a área, nota-se um predomínio de pequenas cristas de morros e vales com direções NW-SE; tal controle da drenagem pode estar associado a juntas de tração. Nota-se também que os pequenos tributários e canais de primeira ordem são controlados preferencialmente pela foliação, com direção NE-SW, e que sofre inflexão para E-W, mais a leste. Alguns vales são controlados por linhas de antigas falhas transcorrentes que atuaram no final do ciclo orogenético Brasiliano, com direções NE-SW e E-W.

A unidade de relevo Morros, na Serra de
Botujuru, é sustentada em grande parte pela unidade litológica de xistos finos e metarenitos, com intercalações subordinadas de filitos, milonitos e quartzitos. Sofre inflexão de NW-SE para E-W, controlada por falhas e zonas de cisalhamento na região (falhas de Botujuru, Terra Preta e Olho d'água). Nas proximidades de Atibaia, o relevo de Morros é sustentado por gnaisses de composição granítica a granodiorítica e granitos.

As coberturas detríticas, tais como os coluviões, condicionam relevos mais suaves, com baixa densidade de drenagem, devido ao fato de serem rochas mais permeáveis. As pequenas manchas de sedimentos argilosos permo-carboníferos do extremo noroeste da área igualmente condicionam relevos suaves, suportados por argilitos, siltitos, diamictitos, folhelhos e ritmitos.

$\mathrm{O}$ rio Jundiaí, em seu percurso ao longo da 
área, apresenta inflexões (cotovelos) na direção do curso principal, ora para NW-SE e ora para E-W, que são controladas por descontinuidades (juntas e falhas), cujos lineamentos podem ser facilmente visualizados em imagens de satélite, fotos aéreas e no Modelo Digital de Terreno. Na região oeste da área, a bacia do rio Jundiaí apresenta distribuição assimétrica, com os afluentes da margem sul muito mais longos, associados a relevo mais suave; na margem norte os afluentes são mais curtos e encaixados. As causas dessa assimetria geral de drenagem não têm sido estudadas em detalhe, embora essa feição morfológica seja encontrada em diversas regiões do sudeste brasileiro, notadamente ao longo das bacias de São Paulo e Taubaté.

\section{Solos e Coberturas Detríticas}

Predominam na área solos estruturados, como cambissolos, latossolos vermelho-amarelo e solos podzólicos vermelho-amarelos (Ross \& Moroz, 1997). Depósitos coluvionares, distribuídos descontinuamente na área, são coberturas inconsolidadas compostas por uma linha basal de seixos, recoberta por material argilo-arenoso maciço com presença de seixos dispersos de quartzo. As linhas de pedras constituem-se em sua maioria de fragmentos de quartzo angulosos a subangulosos com dimensões variáveis, sendo possível encontrar outros litotipos, dos quais o mais freqüente é o quartzito, com mais freqüência nas coberturas situadas na região centrooeste da área (proximidades de Jundiaí e Campo Limpo Paulista).

As coberturas coluvionares recobrem rochas do embasamento cristalino, depósitos paleozóicos e sedimentos terciários-quaternário. Neves (1999) destaca que sua distribuição parece estar vinculada à estrutura do relevo atual, sendo comuns onde as encostas adquirem declividade mais suave. Normalmente, no topo das elevações aparece o nível de seixos e o material superior se espessa em direção às encostas. Porém, em outras situações, a linha de seixos e o material que os recobre podem inclinar-se em direção oposta ao mergulho das vertentes, indicando a possível atuação de falhamentos e subseqüente basculamento.

No extremo NE da área mapeada, próximo a Atibaia, ocorre uma mancha de sedimentos, cuja coloração é variegada em tons amarelados, esbranquiçados, arroxeados, avermelhados até bege. São depósitos areno-argilosos, mal selecionados, sem estrutura estratificada nítida e que incluem estreitas cascalheiras basais. Formam pequena colina alongada de aproximadamente 30 a 40 metros de altura.

Manchas irregulares de depósitos coluvionares foram identificadas, sendo as principais na região de Jundiaí, a oeste da Via Anhangüera, e na região de Campo Limpo Paulista. Trata-se de material avermelhado a amarelado, de composição extremamente variável (areno-silto-argiloso) granulação fina a grossa, mal selecionado. As espessuras variam de poucos metros até mais de uma dezena de metros. Linhas de seixos basais, compostas sobretudo por seixos de quartzito, ocorrem em muitos desses depósitos.

\section{O Mapa geomorfológico de semidetalhe}

O mapa geomorfológico na escala 1:25.000 discrimina sete tipos de relevos (Tabela 2), compatíveis com esse nível de representação. Köhler (2002) assinala que a escala espaço-temporal é fundamental na análise geomorfológica: quanto maior a escala espacial de observação, mais rápida é a dinâmica de sua transformação (e vice-versa). Desse modo, as vantagens desta escala em relação à de 1:50.000, que fêz parte do plano original de pesquisa, devem-se ao fato de que na escala 1:25.000 podem ser representados "pequenos relevos" (Kugler, 1982, apud Köhler, 2002), processos e fenômenos mais atuais. Um fragmento do mapa elaborado encontra-se na Figura 5. A escala adotada é compatível com a densidade de informações coletadas em campo, aliadas à escala dos documentos cartográficos e fotográficos utilizados. Além de ser mais útil para planejamento urbano ou rural de municípios abrangidos, poderá apoiar novos projetos e planos diretores municipais, que abordem uso e ocupação do espaço.

A representação das unidades de relevo foi feita por meio de cores; procurou-se representar com cores mais frias (tons de amarelo), os relevos onde as formas são mais suaves, consequentemente com energias potenciais mais baixas, gradando para cores mais quentes (tons de vermelho) na medida que o relevo se torna mais acidentado, consequentemente com maior energia potencial atuante, que resulta na ocorrência de processos erosivos mais intensos e por vezes mais rápidos.

\section{Dinâmica superficial}

Bigarella et al. (1994, p. 94) destacam que "a sucessão das alternâncias climáticas do Quaternário imprimiu na paisagem, de forma cíclica, as características próprias de cada época, passíveis de serem identificadas na morfologia e nos depósitos superficiais". Durante as épocas mais semi-áridas, concomitantes a níveis de mar mais baixos, teria havido predomínio de morfogênese mecânica, com formação de pedimentos e acumulação de detritos. As épocas de clima mais úmido corresponderiam a um predomínio da erosão fluvial e desenvolvimento de feições mamelonares de relevo.

\section{Paleodinâmica geomorfológica}

O levantamento possibilitou recolher evidências de que os processos superficiais atuantes na área são: reentalhamento de canais, erosão laminar 
Tabela 2 - Resumo dos sete tipos de relevos da área

\begin{tabular}{|c|c|c|c|c|}
\hline $\begin{array}{l}\text { Tipo de } \\
\text { relevo }\end{array}$ & Litologia & Morfografia & Dinâmica superficial & Morfometria (metros) \\
\hline $\begin{array}{c}\text { Planícies } \\
\text { aluviais } \\
(\mathrm{Pa})\end{array}$ & \begin{tabular}{|} 
Aluviões - \\
Areias finas \\
a médias, \\
camadas de \\
argila e \\
argila \\
orgânica
\end{tabular} & $\begin{array}{l}\text { Fonmas deposicionais plandas que } \\
\text { incluem as planícies de inundação, que } \\
\text { de modo geral são de pequenas } \\
\text { extensão, sendo elas mais expressivas } \\
\text { ao longo do rio Jundiaí e no trecho do } \\
\text { ribeirão Onofre, sul de Atibaia. } \\
\text { Associam-se áreas alagadiças devido } \\
\text { ao nível d'água próximo à superfície. }\end{array}$ & $\begin{array}{l}\text { Áreas sujeitas a cheias sazonais. } \\
\text { Deposição de silte e argilas por } \\
\text { decantação. } \\
\text { Terrenos impróprios à ocupação } \\
\text { devido à possibilidade de } \\
\text { incidência de inundações. }\end{array}$ & $\begin{array}{l}\text { Amplitude: }<10 \mathrm{~m} \\
\text { Declividade: } 02 \% \\
\text { Comprimento de } \\
\text { rampa: - } \\
\text { Altitude: } 706950 \mathrm{~m}\end{array}$ \\
\hline $\begin{array}{c}\text { Colinas } \\
\text { (Col) }\end{array}$ & $\begin{array}{l}\text { Coluviões, } \\
\text { sedimentos } \\
\text { correlatos ao } \\
\text { Grupo } \\
\text { Itararé } \\
\text { (PCi), } \\
\text { xistos, } \\
\text { gnaisses. }\end{array}$ & $\begin{array}{l}\text { Formas suaves de relevo com topos } \\
\text { estreitos e convexos. Perfil de vertente } \\
\text { varia entre convexo a retilíneo. Vales } \\
\text { acumulativos e erosivos, abertos e } \\
\text { pouco entalhados. Relevo freqüente- } \\
\text { mente associado a depósitos detríticos. } \\
\text { A densidade de drenagem é baixa com } \\
\text { padrão de drenagem subdendrítico. }\end{array}$ & $\begin{array}{l}\text { Baixa intensidade de erosão } \\
\text { laminar ou em sulcos, reenta- } \\
\text { lhamento de canais e ravinamento. } \\
\text { Mas os processos podem ser } \\
\text { intensificados por desmatamento } \\
\text { e ocupação inadequada. } \\
\text { Terrenos favoráveis à ocupação. }\end{array}$ & $\begin{array}{l}\text { Amplitude: } 4080 \mathrm{~m} \\
\text { Declividade: }<15 \% \\
\text { Comprimento de } \\
\text { rampa: } 1001000 \mathrm{~m} . \\
\text { Densidade de } \\
\text { drenagem: } 1,7 \mathrm{~km} / \mathrm{km}^{2} \\
\text { Altitude: } 706850 \mathrm{~m}\end{array}$ \\
\hline $\begin{array}{l}\text { Colinas e } \\
\text { Morrotes } \\
\text { de } \\
\text { Cimeira } \\
\text { (CMc) }\end{array}$ & $\begin{array}{l}\text { Xistos e } \\
\text { granitos }\end{array}$ & $\begin{array}{l}\text { Topos estreitos, alongados, convexos e } \\
\text { subnivelados geralmente acima de } \\
1.000 \text { metros. Perfil de vertente retilí- } \\
\text { neo a convexo. Vales erosivos e } \\
\text { acumulativos pouco encaixados. A } \\
\text { densidade de drenagem é media a alta } \\
\text { com padrão dendrítico a subdendrítico. }\end{array}$ & $\begin{array}{l}\text { Moderada intensidade de erosão } \\
\text { laminar ou em sulcos, reenta- } \\
\text { lhamento de canal e ravinamento. } \\
\text { Terrenos moderadamente favorá- } \\
\text { veis à ocupação. }\end{array}$ & $\begin{array}{l}\text { Amplitude: } 75-125 \mathrm{~m} \\
\text { Declividade: } 5 \text { - } 35 \% \\
\text { Comprimento de } \\
\text { rampa: } 250375 \mathrm{~m} \\
\text { Densidade de drena- } \\
\text { gem: } 3,2 \mathrm{~km} / \mathrm{km}^{2} \\
\text { Altitude: } 900-1025 \mathrm{~m}\end{array}$ \\
\hline $\begin{array}{c}\text { Colinas e } \\
\text { Morrotes } \\
\text { (CMt) }\end{array}$ & \begin{tabular}{|} 
Filitos, \\
xistos, \\
metarenitos, \\
gnaisses e \\
granitos
\end{tabular} & $\begin{array}{l}\text { Topos estreitos, convexos e alongados, } \\
\text { que se encontram subnivelados, com } \\
\text { orientações NE-SW e NW-SE. O perfil } \\
\text { de vertente varia de retilíneo a conve- } \\
\text { xo. Padrão de drenagem sub-retangular } \\
\text { e subdendritico com densidade alta. }\end{array}$ & $\begin{array}{l}\text { Moderada intensidade de erosão } \\
\text { laminar e em sulcos, ravinamento } \\
\text { e reentalhamento de canal. } \\
\text { Terrenos moderadamente favorá- } \\
\text { veis à ocupação. }\end{array}$ & $\begin{array}{l}\text { Amplitude: } 50 \text { - } 80 \mathrm{~m} \\
\text { Declividade: } 5 \text { - } 35 \% \\
\text { Comprimento de } \\
\text { rampa: } 100 \text { - } 400 \mathrm{~m} \\
\text { Densidade de drena- } \\
\text { gem: } 3,6 \mathrm{~km} / \mathrm{km}^{2} \\
\text { Altitude: } 750890 \mathrm{~m} \\
\end{array}$ \\
\hline $\begin{array}{c}\text { Morros e } \\
\text { Morrotes } \\
\text { (MMt) }\end{array}$ & \begin{tabular}{|} 
Xistos, \\
metarenitos, \\
gnaisses e \\
pequenos \\
corpos \\
graníticos \\
(stocks).
\end{tabular} & $\begin{array}{l}\text { Topos subnivelados, convexos, } \\
\text { estreitos e alongados; predominando } \\
\text { uma orientação dominante para NW- } \\
\text { SE. O perfil de vertente varia entre } \\
\text { retilíneo a convexo. Vales erosivos e } \\
\text { acumulativos estreitos. Padrão de dre- } \\
\text { nagem varia de dendrítico a subden- } \\
\text { drítico com densidade de drenagem } \\
\text { alta. }\end{array}$ & $\begin{array}{l}\text { Moderada a alta intensidade de } \\
\text { erosão laminar e em sulcos, } \\
\text { ravinamento e reentalhamento de } \\
\text { canal. } \\
\text { Terrenos moderadamente } \\
\text { a pouco favoráveis à ocupação. }\end{array}$ & $\begin{array}{l}\text { Amplitude: } 50 \text { - } 110 \mathrm{~m} \\
\text { Declividade: } 5 \text { - } 40 \% \\
\text { Comprimento de } \\
\text { rampa: } 125 \text { - } 500 \mathrm{~m} \\
\text { Densidade de drena- } \\
\text { gem: } 3,6 \mathrm{~km} / \mathrm{km}^{2} \\
\text { Altitude: } 750930 \mathrm{~m}\end{array}$ \\
\hline $\begin{array}{l}\text { Morros } \\
\text { (Mr) }\end{array}$ & $\begin{array}{l}\text { Xistos, } \\
\text { gnaisses e } \\
\text { granitos }\end{array}$ & $\begin{array}{l}\text { Topos estreitos, convexos e irregulares. } \\
\text { Perfis de vertente retilíneos a conve- } \\
\text { xos, localmente com presença de blo- } \\
\text { cos nas vertentes. Vales erosivos. A } \\
\text { densidade de drenagem varia de média } \\
\text { a alta com padrões dendríticos e sub- } \\
\text { dendríticos. É um relevo que vem sen- } \\
\text { do entalhado principalmente por canais } \\
\text { de primeira, segunda e terceira ordens; } \\
\text { corresponde às cabeceiras dos afluen- } \\
\text { tes dos rios Jundiaí, Atibaia e Juqueri. }\end{array}$ & $\begin{array}{l}\text { Alta intensidade de erosão laminar } \\
\text { e em sulcos, ravinamentos, } \\
\text { reentalhamentos de canais, raste- } \\
\text { jos e queda de blocos. } \\
\text { Terrenos desfavoráveis para } \\
\text { ocupação ou ocupáveis sob } \\
\text { restrições. }\end{array}$ & $\begin{array}{l}\text { Amplitude: } 100-150 \mathrm{~m} \\
\text { Declividade: } 12-70 \% \\
\text { Comprimento de } \\
\text { rampa: } 125 \text { - } 375 \mathrm{~m} \\
\text { Densidade de drena- } \\
\text { gem: } 3,3 \mathrm{~km} / \mathrm{km}^{2} \\
\text { Altitude: } 775-1000 \mathrm{~m}\end{array}$ \\
\hline $\begin{array}{l}\text { Morros } \\
\text { com } \\
\text { Topos } \\
\text { Agudos } \\
\text { (Mta) }\end{array}$ & $\begin{array}{c}\text { Metarenitos, } \\
\text { Quartzitos e } \\
\text { de filitos } \\
\text { intercalados } \\
\text { com } \\
\text { metarenitos } \\
\text { impuros e } \\
\text { quartzitos }\end{array}$ & $\begin{array}{l}\text { Topos aguçados, estreitos, alongados e } \\
\text { subparalelos. Vales erosivos muito } \\
\text { entalhados e estreitos, orientados } \\
\text { preferencialmente para NW-SE. O } \\
\text { perfil de vertente é retilíneo. A densi- } \\
\text { dade de drenagem é alta com padrões } \\
\text { de drenagem subparalelos; notam-se } \\
\text { alguns vales controlados por linhas de } \\
\text { falhas, com orientação E-W. }\end{array}$ & $\begin{array}{l}\text { Alta intensidade de erosão laminar } \\
\text { e em sulcos, reentalhamento de } \\
\text { canais, queda de blocos e } \\
\text { ravinamento. A preservação da } \\
\text { vegetação reduz a intensidade dos } \\
\text { processos superficiais. } \\
\text { Terrenos desfavoráveis para } \\
\text { ocupação ou ocupáveis sob } \\
\text { restrições. }\end{array}$ & $\begin{array}{l}\text { Amplitude: } 100-200 \mathrm{~m} \\
\text { Declividade: } 15-90 \% \\
\text { Comprimento de } \\
\text { rampa: } 100-400 \mathrm{~m} \\
\text { Densidade de drena- } \\
\text { gem: } 4,0 \mathrm{~km} / \mathrm{km}^{2} \\
\text { Altitude: } 800-1050 \mathrm{~m}\end{array}$ \\
\hline
\end{tabular}




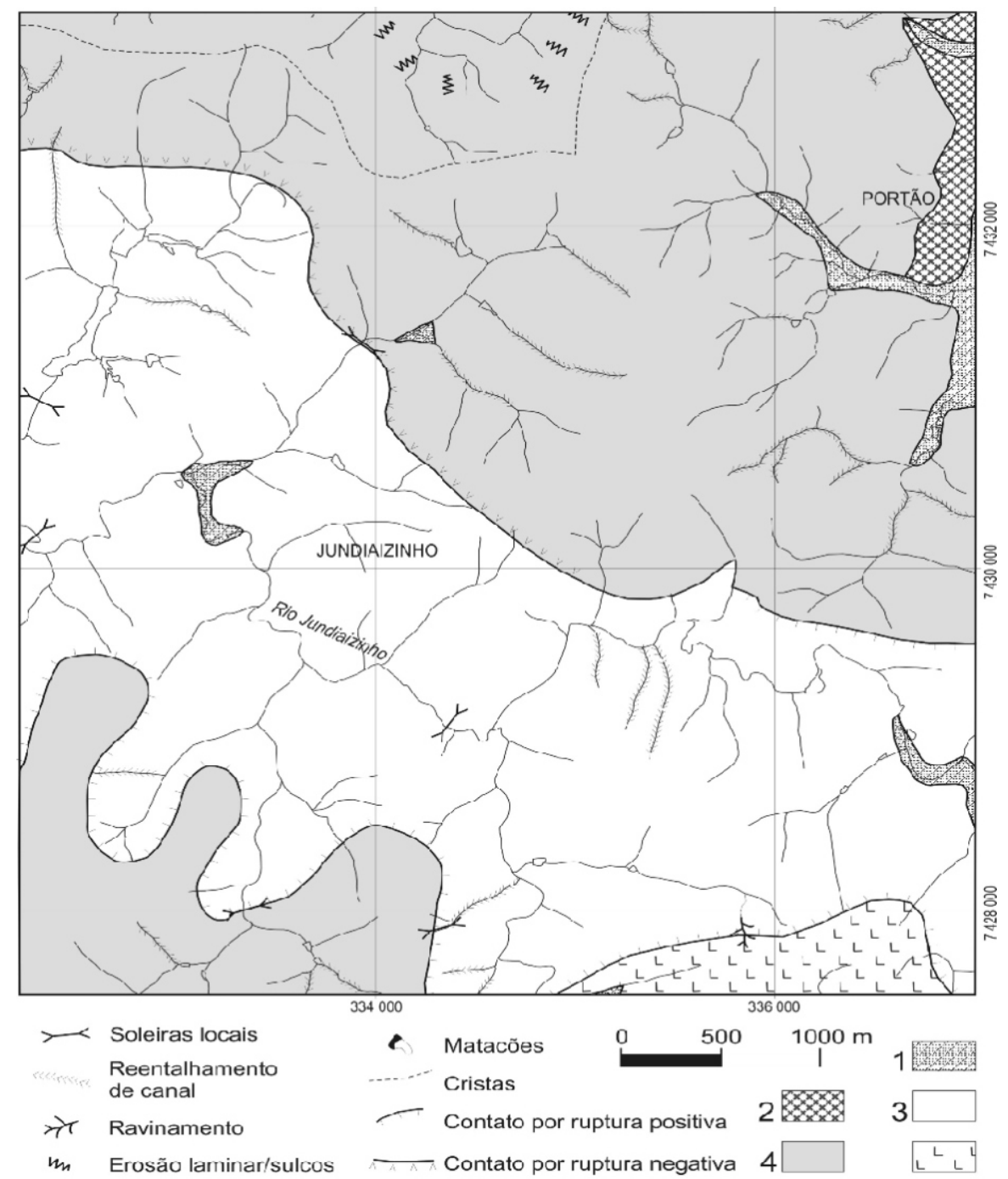

Figura 5: Fragmento do mapa geomorfológico de semidetalhe, representado em tons de cinza. Convenções: 1 Planícies Aluviais, 2 - Colinas, 3 - Morros e Morrotes, 4 - Morros, 5 - Colinas e Morrotes de Cimeira. Escala aproximada 1:25.000; coordenadas UTM correspondentes a um segmento da folha Atibaia (SF.23Y-C-III-2)

ou em sulcos, ravinamento, deslizamento, queda de blocos, boçorocamento e assoreamento. Esses processos, a partir dos registros descontínuos identificados, revelam-se variáveis quanto à intensidade e freqüência ao longo de toda a área.

O reentalhamento de canais é mais freqüente no relevo Morros, associados às cabeceiras dos rios Jundiaí, Atibaia e Juqueri. Nos afluentes do rio Atibaia este processo de reentalhamento é freqüente, mas também ocorre com intensidade moderada em relevos Morros e Morrotes e é menos freqüente nas unidades de relevos Colinas e Morrotes, Colinas, Morros com Topos Agudos e Colinas e Morrotes de Cimeiras.

As ocorrências de ravinamentos e erosão laminar são mais freqüentes na unidade Morros, em locais onde predominam declividades altas (acima de $15 \%$ ) embora possam ser identificados também nas demais unidades. Um dos exemplos mais notáveis, na unidade Morros, é o chamado Jardim Vitória Régia II, situado a SW da cidade de Atibaia. Ali observa-se acentuado grau de degradação da paisagem: em muitos lotes a remoção do horizonte superficial de solos, em zonas de encostas íngremes, expôs à erosão o frágil solo de alteração de xistos. Ao longo de caminhos e estradas locais também se observam efeitos de erosão acelerada. Na unidade de relevo Colinas processos de ravinamentos e erosão laminar são incomuns, embora possam ser intensificados em algumas zonas de ocupação desordenada.

Devido à intensificação dos processos erosivos nas encostas, nota-se, freqüentemente, processos de assoreamento de canais, lagos e vales, um aspecto muitas vezes constatado em campo. $\mathrm{O}$ assoreamento representa a acumulação intermitente de grandes volumes de sedimentos que excedem a capacidade de transporte da rede local de drenagem após episódios de chuvas intensas. Lagos e pequenos reservatórios artificiais de água são parcial ou completamente preenchidos por sedimentos arenosos ou areno-argilosos provenientes da erosão de solos 
expostos e materiais de regolito a montante. $\mathrm{O}$ fenômeno é mais freqüente nas proximidades do rio Jundiaí e a NW da cidade de Campo Limpo Paulista, entretanto também ocorre em outras partes, notadamente na unidade de relevo Morros.

Foram identificados efeitos dos fenômenos de queda de blocos e deslizamentos nas proximidades de Mariporã, associados às unidades Morros, na região da Serra dos Cristais, na unidade Morros com Topos Agudos, e, nas proximidades de Campo Limpo Paulista, em encostas mais íngremes do relevo de Colinas e Morrotes.

\section{Dinâmica geomorfológica moderna}

Processos comuns na área são os desplacamentos, que geralmente ocorrem após a abertura de estradas e cortes para abertura de loteamentos, sobretudo em exposições dispostas paralelamente à foliação da rocha. Os planos de foliação favorecem, ao longo do tempo, o aparecimento de extensas descontinuidades planares. Uma vez que as orientações dos cortes são inadequadas, a continuidade dos processos intempéricos e sobretudo a remoção de material da base dos taludes pode agravar a instabilidade local, favorecendo os movimentos de massa, na forma de deslizamentos e desplacamentos.

No centro da cidade de Campo Limpo Paulista, próximo ao Paço Municipal, há um lamentável exemplo dessa dinâmica natural de difícil controle. Ali, dois fatores adicionais ampliam consideravelmente esses efeitos: a altura e a forte declividade dos taludes.

A região exibe contrastes notáveis de relevo, que por sua vez condicionam os padrões de ocupação regionais. Um bom exemplo de condicionamento da ocupação ocorre ao longo do rio Jundiaí (cidades de Jundiaí, Várzea Paulista e Campo Limpo Paulista), onde a presença de relevo mais suave (Colinas e Planície Aluvial) propiciou a instalação pretérita da parte urbana desses municípios, por meio de intenso trabalho de terraplenagem que possibilitou $o$ rebaixamento de morros e permitiu que as ruas e lotes implantados nas cidades de Várzea Paulista e Campo Limpo Paulista ganhassem uma configuração menos íngreme e portanto mais adequada para urbanização.

Em Campo Limpo Paulista, o loteamento popular existente entre os bairros Jardim Europa e Parque Internacional é característico: foi instalado após terraplenagem que suavizou o terreno, minimizando os processos erosivos em encostas que anteriormente exibiam declividades médias a altas. É clara a existência de um talude ao fundo das ruas e casas, que constitui uma prática adequada dos construtores, pretérita, ou seja, o rebaixamento dos morros para permitir a instalação do sítio urbano. Isso minimizou a ocorrência de processos de erosão acelerada por meio de um mecanismo bastante simples. Como o talude permanece desprotegido pela vegeta- ção, a possibilidade de incidência de ravinamentos e escorregamentos restringe-se àquele local.

Contudo, hoje em dia a ocupação avançou para as encostas mais íngremes (declividades $<20 \%$ ) e o modelo modificou-se: o padrão atual não obedece a qualquer planejamento, passando essas áreas a apresentar um risco potencial. É frequente também a ocupação do relevo de Planícies Aluviais, que são sujeitas a periódicas inundações. Os problemas mais comuns são a fixação da população em loteamentos (ou invasões) em zonas de encostas íngremes, com risco de escorregamentos e erosão concentrada; a ocupação de baixadas também pode desrespeitar as limitações naturais e ocasionar risco de assoreamento e inundações localizadas (Carneiro, 2000).

Foram observados diversos casos de ocupações em áreas de risco, como ocupações no sopé de encostas íngremes, onde muitas vezes são feitos cortes para instalação das fundações de casas. Em alguns casos, na parte superior das encostas, observaram-se rachaduras subparalelas no asfalto de ruas e avenidas locais. Isso representa risco potencial em estações chuvosas, onde a saturação d'água pode gerar deslizamentos que soterrarão as construções abaixo. Outra situação de risco, são as freqüentes ocupação de vales encaixados, que ficam sujeitas à concentração de fluxo d'água pluvial em chuvas mais fortes. As ocupações de Planícies Aluviais também são freqüentes na área, sujeitas a inundações periódicas. São freqüentes as áreas de bota-fora sem nenhum planejamento, estando as áreas sujeitas a deslocamento de massas e intensificação de processos erosivos.

As aberturas de estradas paralelas à foliação, além de favorecer processos de deslizamentos, principalmente nas estações mais chuvosas, facilitam a formação de sulcos ao longo da estrada, pelo escoamento concentrado de águas pluviais. Isso se deve aos planos de foliação que favorecem os processos de erosão. Nos casos de abertura de estradas transversais à foliação o fenômeno é minimizado.

$\mathrm{Na}$ unidade de Morros com Topos Agudos, concentrada na Serra dos Cristais, encontra-se o relevo mais acidentado da área, com declividade predominante acima de $20 \%$. Isso pode ser atribuído ao fato de esse relevo ser sustentado por rochas mais resistentes ao processo erosivo, sendo ele composto de quartzitos, metarenitos e intercalações entre filitos e metarenitos. Devido aos processos de erosão diferencial esse relevo destaca-se na paisagem, enquanto que no seu entorno, constituído dominantemente por seqüências de filitos e xistos, o relevo se encontra mais rebaixado pela erosão.

\section{Considerações Finais}

A escala de semidetalhe adotada (1:25.000) permitiu mapear, sistematicamente, algumas feições de relevo, como: ravinas, erosões laminares e em sulcos, reentalhamento de canais, boçorocas, alguns 
campos de matacões e pequenas soleiras locais. As ocorrências são representadas por meio de símbolos convencionais, para facilitar a leitura do mapa, ou seja, sem restringir o entendimento cartográfico aos especialistas.

Confirma-se, uma vez mais, que o arcabouço lito-estrutural condiciona as formas de relevo (Almeida, 1964), como por exemplo vales encaixados em zonas de fraqueza geradas por antigas falhas transcorrentes, ou falhas devidas a possíveis reativações. A transição entre diferentes zonas geomorfológicas reflete desníveis topográficos gerados por erosão diferencial: relevos mais altos e acidentados são suportados por rochas resistentes e a presença de pequenas soleiras locais associadas às descontinuidades e contrastes de resistência à erosão dos diferentes litotipos. As soleiras locais, que podem aparecer associadas a rupturas positivas de revelo, podem também marcar a transição entre tipos de relevos mapeáveis. $\mathrm{O}$ controle estrutural da rede de drenagem é dado por descontinuidades associadas à foliação das rochas, falhas e, ou, sistemas de juntas. O reentalhamento de canais pode estar associado a várias causas, como intensificação do processo erosivo devido às atividades decorrentes da ocupação moderna, rebaixamento no nível de base da rede de drenagem local ou reativações devidas à neotectônica. Em alguns locais onde há ocorrência de reentalhamento também estão presentes processos de ravinamento e registram-se zonas afetadas por erosão laminar ou em sulcos.

Vale ressaltar que a área vem sofrendo intenso processo de ocupação, que gera muitas feições pontuais ou lineares derivadas da interação da atividade antrópica com os processos erosivos: abertura de estradas, terraplenagens, aterros, dentre tantas outras. Tais processos de erosão acelerada associam-se a zonas portadoras de declividades mais elevadas (acima de 10\%). Uma hipótese formulada no início dos trabalhos, corroborada pelas observações, é a de que, no projeto geotécnico de áreas onde predominam substratos de rochas foliadas, submetidos a processos intempéricos, com altas declividades e forte avanço da ocupação, os conhecimentos de Geologia, Geologia Estrutural e Geomorfologia são essenciais para prevenção/ minimização de acidentes geológico-geotécnicos, devendo fazer parte de estudos que precedam a abertura de estradas e loteamentos.

\section{Agradecimentos}

Os autores agradecem o apoio da FAPESP, pela bolsa de iniciação científica (Proc. 00/00316-8), que permitiu o desenvolvimento do trabalho e o amadurecimento acadêmico do aluno de graduação (Geologia) J. J. de Souza. Os autores agradecem ao CNPq - Conselho Nacional de Desenvolvimento Científico e Tecnológico pela bolsa de produtividade em pesquisa concedida a um deles (CDRC), processo
303208/87-2 (NV). Agradecem ainda aos demais exbolsistas do Projeto Jundiati, pelo cooperação ao longo do projeto, ao Prof. Dr. Antônio Carlos Vitte pelas sugestões a uma versão prévia do trabalho e ao Prof. Dr. Fernando Flávio Marques de Almeida pelas valiosas sugestões que permitiram melhorar o manuscrito. Agradecem ainda a dois anônimos revisores da Revista Brasileira de Geomorfologia, pelas pertinentes sugestões.

\section{Referências bibliográficas}

AB'SABER, A.N. (1992) A Serra do Japi, sua origem geomorfológica e a teoria dos refúgios. In: MORELLATO, L.P.C. (org.) 1992. História Natural da Serra do Japi. Ecologia e preservação de uma área florestal no sudeste do Brasil. Campinas: Ed. UNICAMP/FAPESP. p. 12-23.

AB'SABER, A.N. (2000) Summit surfaces in Brazil. Rev. Bras. Geoc., v. 30, n. 1, 2 and 3, p. 28-31.

ALMEIDA, E.B.; CARVALHO, W.S. de; HASUI, Y.; ALMEIDA, F.F.M. de; GONZALES FILHO, F.; SHIMADA, H.; BELJAVSKIS, P.; SUSLICK, S.B.; SANTOS, M.C.S.R. dos; ALBAMONTE, L.; FERNANDES, J;L. (1981) Mapa de jazidas e ocorrências minerais do Estado de São Paulo. São Paulo: IPT. 3V. (IPT, Monografias, 4).

ALMEIDA, F.F.M. (1964) Fundamentos geológicos do relevo paulista. In: INSTITUTO GEOGRÁFICO E GEOLÓGICO. Geologia do Estado de São Paulo. São Paulo: IGG. P. 167-263. (IGG. Boletim, 41)

ALMEIDA, F.F.M. (1976) The system of continental rifts bordering the Santos Basin, Brazil. An. Acad. brasil. Ciênc., v. 48 (supl.), p. 15-26. (Proc. Intern. Symp. on Continental Margins of Atlantic type, October 1975).

ALMEIDA, F.F.M. de; CARNEIRO, C.D.R. (1998) Origem e evolução da Serra do Mar. Rev. Bras. Geoc. v. 28, n. 2, p. 135-150.

ALMEIDA, F.F.M. de; HASUI, Y.; PONÇANO, W.L.; DANTAS, A.S.L.; CARNEIRO, C.D.R.; MELO, M.S. de.; BISTRICHI, C.A. (1981) Nota Explicativa do Mapa Geológico do Estado de São Paulo. São Paulo, IPT. 126p. (IPT, Monografias 6).

ALMEIDA, F.F.M.; HASUI, Y.; BRITO-NEVES, B.B.; FUCK, R.A. (1977) Províncias estruturais brasileiras. In: SIMPÓSIO GEOLOGIA DO NORDESTE, 8, 1977, Recife. Atas. Recife: SBG/NNE. p.363-391.

BIGARELLA, J.J. (coord.); BECKER, R.D.; SANTOS, G.F.; PASSOS, E.; SUGUIO, K. (1994) Estrutura e Origem das Paisagens Tropicais e Subtropicais. Florianópolis: Ed. 
UFSC, v. 1, 425 p.

BISTRICHI, C.A.; CARNEIRO, C.D.R.; DANTAS, A.S.L.; PONÇANO, W.L.; CAMPANHA, G.A. da C.; NAGATA, N.; ALMEIDA, M.A. de; STEIN, D.P.; MELO, M.S. de; CREMONINI, O.A.; HASUI, Y.; ALMEIDA, F.F.M. de. (1981) Mapa Geológico do Estado de São Paulo. São Paulo: IPT. (IPT, Monografias 6, anexo).

CARNEIRO, C.D.R. (1999) Estruturas planares e vulnerabilidade das rochas à erosão na região de Campo Limpo-Francisco Morato, SP. In: SIMP. NAC. EST. TECTÔNICOS., 7, Lençóis, 1999 e INTERN. SIMP. ON TECTONICS OF THE BRAZILIAN GEOLOGICAL SOCIETY., 1, Lençóis, 1999. Anais..., Lençóis: SBG/NBA-SE. Seção 6, p. 29-33.

CARNEIRO, C.D.R. (2000) Modelado do relevo e riscos naturais associados às ocupações urbanas da região de Jundiaí-Atibaia. In: Simpósio Nacional de Geomorfologia, 3, Campinas (SP). Anais - vol. 1... Campinas: UGB.p. 26.

CARNEIRO, C.D.R. (2001) Geologia da região de Jundiai-Atibaia. Projeto Evolução crustal da região de Jundiaí-Atibaia e implicações conceituais para ensino de campo em geologia e planejamento da ocupação. Campinas (SP). Apoio: Fundação de Amparo à Pesquisa no Estado de São Paulo - FAPESP. 90p., 9 anexos (3 mapas). (Relatório Científico Final, 3, FAPESP/CNPq).

CARNEIRO, C.D.R.; BISTRICHI, C.A.; PONÇANO, W.L.; ALMEIDA, M.A. de.; ALMEIDA, F.F.M. de; SANTOS, M.C.S.R. dos. (1981) Mapa Geomorfológico do Estado de São Paulo, ao milionésimo. São Paulo: IPT. (IPT, Monografias 5, anexo).

COMPANHIA DE PESQUISA DE RECURSOS MINERAIS (CPRM). (1991) Projeto Integração Geológica da Região Metropolitana de São Paulo. São Paulo: CPRM. (relatório interno, mapas, inédito).

FERNANDES, N.F.; GUIMARÃES, R.F.; GOMES, R.A.T.; VIEIRA, B.C.; VIEIRA, A.C.F. (2000) Condicionantes geomorfológicos dos deslizamentos nas encostas: teoria, evidências de campo e modelos de previsão. In: Simpósio Nacional de Geomorfologia, 3, Campinas (SP). Anais - vol. 1... Campinas: UGB. p. 142.

HASUI, Y.; ALMEIDA, F.F.M de; BRITO-NEVES, B.B. (1978) As estruturas Brasilianas. In: C ONGRESSO BRASILEIR O DE GEOLOGIA, 30, 1978, Recife. Anais... Recife: SBG, v. 6, p. 2423-2437.

INSTITUTO GEOLÓGICO (IG). (1993) Subsídios do meio físico-geológico ao planejamento do município de Campinas, SP, 1:50.000. São
Paulo: Instituto Geológico. 2v. (Relatório Técnico).

KÖHLER, H.C. (2002) A escala na análise geomorfológica. Rev. Bras. Geomorfologia. Ano 3, n. 1, p. 21-31.

NEVES, M. (1999) Evolução cenozóica da região de Jundiai, SP. Rio Claro: Inst. Geoc. Ciênc. Exatas UNESP. (Dissertação de Mestrado, IGCE-UNESP).

PIRES NETO, A.G. (1991) As abordagens sintéticohistórica e analítico-dinâmica, uma proposição metodológica para a geomorfologia. São Paulo: FFLCH/USP. (Tese de Doutoramento, FFLCH/USP).

PIRES NETO, A.G.; CASTRO, S.A.P.; MENDES, E.A.A.; GOULART, A.C.O.; TOMINAGA, L.K. (1993) Geomorfologia da Município de Campinas, in: INSTITUTO GEOLÓGICO. Subsídios do meio-físico-geológico ao planejamento do município de Campinas (SP), São Paulo, Relatórios Técnicos, vol II, cap. 3, p 52-81.

PONÇANO, W.L.; ALMEIDA, F.F.M. (1993) Superficies erosivas nos planaltos cristalinos do leste paulista e adjacências: uma revisão. Cadernos IG/UNICAMP, v. 3, n. 1, p. 55-90.

PONÇANO, W.L.; BISTRICHI, C.A.; CARNEIRO, C.D.R.; ALMEIDA, M.A. de; PIRES NETO, A.C.; ALMEIDA, F.F.M. de. (1979) $O$ conceito de sistemas de relevo aplicado ao mapeamento geomorfológico do Estado de São Paulo. In: SIMP. REG. GEOL., 2, Rio Claro, 1979. Atas... Rio Claro: SBG/NSP. v. 2, p. 253262.

PONÇANO, W.L.; CARNEIRO, C.D.R.; BISTRICHI, C.A.; ALMEIDA, F.F.M. de.; PRANDINI, F.L. (1981) Notícia Explicativa do Mapa Geomorfológico do Estado de São Paulo. São Paulo: IPT. 94p. (IPT, Monografias 5).

PONÇANO, W.L.; CARNEIRO, C.D.R.; BISTRICHI, C.A.; PIRES NETO, A.G.; SANTOS,. M.C.S.R. dos; ALMEIDA, M.A. de.; ALMEIDA, F.F.M. de. (1980) Carta Geomorfológica do Estado de São Paulo na escala de 1:2 500 000, com base no conceito de sistemas de relevo. In: CONGR. BRAS. GEOL., 31, Baln. Camboriú, 1980. Anais... Baln. Camboriú: SBG. v. 2, p. 1013-1015.

RICCOMINI, C. (1989) O rift continental do sudeste do Brasil. São Paulo: 256p. (tese de doutoramento. IG-USP).

ROSS, J.L.S.;MOROZ, I.C. (1997) Notícia Explicativa do Mapa Geomorfológico do Estado de São Paulo. Departamento Geografia. FFLCH USP. 